\title{
Examinarea dimensiunilor comportamentului de tip A în relația dintre stresorii ocupaționali și reacțiile la stres în munca de poliție*
}

\author{
Anca-Maria Lazăr' ${ }^{1}$, Claudia Lenuța Rus ${ }^{2}$
}

\begin{abstract}
The literature has highlighted the presence of a higher proportion of Type A behavior among police officers compared to the general population. Thus, the present study examined the predictive role of two components of Type A behavior (impatience and drive) on stress reactions and the moderator effect of these dimensions in the relation stressors-reactions to stress in police work. To assess the variables included in this study it was used scales from Occupational Stress Indicator-2 (OSI-2; Cooper, Sloan, \& Williams, 1988). These scales were completed by 108 policemen. The results showed that impatience is the only predictor of some aspects of physical (tempered behavior, energy) and mental health (satisfaction, peace of mind). The data show that impatience and drive do not moderate the relationship between stressors and reactions to stress represented by work satisfaction, satisfaction toward organization, satisfaction with mental well-being, peace of mind, tempered behavior and energy. The impatience has moderated the tension generated by the workload and responsibilities on activism. The drive has moderated the relation between workload and activism. Based on these results, it has been discussed the validity of the conceptual model of the OSI-2 and the development of occupational stress management interventions in police work.
\end{abstract}

Keywords: occupational stressors, Type A behavior, impatience, drive, satisfaction at work, mental health, physical health

\section{Résumé}

La littérature a mis en évidence la présence d'une proportion plus élevée de comportement de Type A chez les policiers par rapport à la population générale. A partir de ce point, cette étude a examiné le rôle prédictif des deux dimensions de Type A de comportement (l'impatience et l'impulsivité) sur les réactions au stress et l'effet modérateur de ces dimensions dans la relation facteurs de stress-réactions au stress dans le travail policier.Pour évaluer les variables inclues dans l'étude, on a étaient utilisées des échelles de l'Indicateur du Stress au Travail2 (OSI-2; Cooper, Sloan, \& Williams, 1988). Cet instrument a été complété par 108 policiers. Les résultats montrent que l'impatience est un prédicteur de certains aspects de la santé physique (le comportement tempéré, l'énergie) et mentale (la satisfaction, la tranquillité d'esprit).Les données montrent que l'impatience et l'impulsivité ne modère pas la relation entre les facteurs de stress au travailet les réactions au stress représentées par la satisfaction au travail, la satisfaction envers l'organisation, la satisfaction du bien-être mental, la tranquillité de l'esprit, le comportement trempé et l'énergie.L'impatience a modéré la tension générée par la charge de travail et les responsabilités sur l'activisme. L'impulsivité a modéré la relation entre la charge de travail et l'activisme. S'appuyant sur les résultats, on a été discuté de la validité du modèle conceptuel de l'OSI-2 et le développement des interventions de gestion du stress dans le travail policier.

Mots-clés : facteurs de stress au travail,Type A de comportement, l'impatience, l'impulsivité, satisfaction au travail, santé mentale, santé physique

* Autorii doresc să mulțumească pentru suportul financiar din programul co-finanțat de Programul Operațional Sectorial pentru Dezvoltarea Resurselor Umane 2007-2013, Contract POSDRU 6/1.5/S/4 - „Studii doctorale, factor major de dezvoltare al cercetărilor socio-economice și umaniste".

Adresa de corespondență: albas_trupsycho@yahoo.com.

${ }^{1}$ Ministerul Administrației şi Internelor, Unitatea Poliție.

${ }^{2}$ Universitatea Babeș-Bolyai, Cluj-Napoca. 


\section{Rezumat}

În literatura de specialitate a fost evidențiată prezența unei proporții mai ridicate de comportamente de Tip A printre polițişti în comparație cu populația generală. Pornind de la acest aspect, studiul de față a examinat rolul predictiv a două componente ale Tipului A de comportament (nerăbdare și impulsivitate) asupra reacțiilor la stres şi efectul moderator al acestor dimensiuni în relația stresori-reacții la stres în munca de poliție.Pentru evaluarea variabilelor incluse în studiu,s-au utilizat scale din Indicatorul de Stres Ocupațional-2 (OSI-2; Cooper, Sloan, \& Williams, 1988). Acest instrument a fost completat de către 108 polițiști.Rezultatele au arătat că nerăbdarea constituie un predictor al unor aspecte ale stării de sănătate fizică (comportament temperat, energia) și mentală (mulțumirea, liniștea sufletească). Datele obținute evidențiază faptul că nerăbdarea și impulsivitatea nu moderează relațiile dintre stresori şi reacțiile la stres reprezentate de satisfacția față de muncă și organizație, mulțumirea față de starea de bine mentală, liniștea sufletească, comportamentul temperat și energie. Nerăbdarea a moderat tensiunea generată de încărcarea muncii și responsabilități asupra activismului. Impulsivitatea a moderat relația dintre încărcarea muncii și activism. Pe baza rezultatelor obținute a fost discutată validitatea modelului conceptual al OSI-2 și dezvoltarea unor intervenții de management al stresului ocupațional în munca de poliție.

Cuvinte-cheie: stresori ocupaționali, comportament de Tip A, nerăbdare, impulsivitate, satisfacția muncii, sănătate mentală, sănătate fizică

\section{Introducere}

Stresul la locul demuncă constituie un hazard ocupațional în cadrul vieții moderne (Stichcomb, 2004), care are implicații negative atât asupra angajatului, cât și asupra organizației (McCreary \& Thompson, 2006). În ultimul timp, s-a pus un accent tot mai mare pe studiul stresului ocupațional în munca de poliție (Brown \& Campbell, 1994; Toch, 2002; apud. Malach-Pines \& Keinan, 2007), deoarece această muncă este considerată a fi una stresantă, solicitantă, în cadrul căreia polițiștii sunt expuşi unor situații amenințătoare și violente (Dick, 2000; Abdollahi, 2002; Mikkelsen \& Burke, 2004).

În literatura de specialitate pot fi identificate variate surse de stres în munca de poliție (Antoniu, 2009), care pot fi grupate în patru mari categorii: stresori relaționați cu sarcina (de exemplu, încărcarea muncii), stresori organizaționali (de exemplu, lipsa oportunităților de avansare), stresori externi (de exemplu, sistemul judiciar) şi stresori personali (de exemplu, conflictul muncă-familie). Indiferent de natura lor, stresorii ocupaționali împiedică procesele de îndeplinire a sarcinilor de muncă, solicitând din partea angajatului un nivel mai mare al efortului în muncă (Sonnentag \& Jelden, 2009). Această clasificare include atât stresori comuni și altor ocupații (de exemplu, încărcarea muncii), precum și stresori specifici muncii de poliție (de exemplu, schimbul de focuri). Deşi s-a identificat că stresorii ocupaționali sunt în mod tipic relaționați cu un nivel crescut al stresului perceput, precum și al reacțiilor la acțiunea acestora (Jones, Flynn \& Kelloway, 1995), nu toți stresorii produc aceleași efecte la toți indivizii. Potrivit abordării cognitive a stresului (Lazarus, DeLongis, Folkman \& Gruen, 1985), aceleaşi condiții speciale de muncă determină reacții diferite la indivizi diferiți, datorită evaluărilor subiective pe care aceștia le fac asupra situațiilor şi asupra resurselor disponibile pentru a face față acestor situații. Diferențele individuale, precum tipul A de comportament, pot contribui la înțelegereamodului dacă o situație este percepută ca fiind stresantă și, în consecință dacă ea va conduce la efecte negative pe plan fiziologic, fizic și/sau psihologic.

\section{Pattern-ul comportamental de tip A}

Inițial înțeles ca o variabilă tipică de personalitate, Tipul A de comportament (Jamal \& Baba, 2003) este conceptualizat în prezent ca un pattern de comportament ce se dezvoltă din interacțiunea solicitărilor de mediu cu caracteristicile de personalitate ale individului (Schmied \& Lawler, 1986, apud. Capotescu, 2006). Indivizii care manifestă acest pattern de comportament sunt caracterizați prin ambiție, nerăbdare, ostili- 
tate, sunt tot timpul în acțiune, nerăbdători, perfecționiști, presaţi mereu de timp, au dorințe puternice de realizare, ritm al vorbirii accelerat, tendinţa de a provoca şi de a fi în competiție cu alții (Friedman \& Booth-Kewley, 1987). Caracteristica centrală a tipului A de comportament este o luptă neîncetată de a câştiga cât mai mult într-un timp cât mai scurt. În contrast cu acest tip de comportament, a fost descris pattern-ul comportamental de tip B caracterizat ca relaxat, răbdător, liniștit, controlat, influențabil, necompetitiv (Contrada, 1989). Cu toate că Tipul A de comportament este conceptualizat în termeni comportamentali distincți, cele mai multe studii empirice au utilizat măsurători globale ale acestui construct, măsurători care reflectă de fapt un amestec al complexității de comportamente reunite sub denumirea de Tip A de comportament (Edwards \& Baglioni, 1991). Edwards, Baglioni și Cooper (1990) au chestionat validitatea măsurătorilor globale ale Tipului A de comportament, abordând acest concept ca fiind mai degrabă unul multidimensional. În plus, rezultatele contradictorii ale unor studii bazate pe măsuri imprecise, globale ale tipului A de comportament i-au determinat pe cercetători să se focalizeze pe identificarea subcomponentelor specifice care sunt cele mai predictive pentru bolile cardiovasculare și pentru o serie de variabile relevante pentru mediul organizațional, cum ar fi performanța în muncă (Jamal, 2007). Multe dintre caracteristicile Tipului A de comportament sunt susţinute empiric de date obținute de la eșantioane diferite care provin din variate contexte culturale și naționale (Lavanco, 1997; Lee, Jamieson \& Earley, 1996; Matthews, 1988; apud. Jamal, 2007), cum ar fi de exemplu dimensiunile reprezentate de sârguinţă, nerăbdare, criză de timp și ostilitate.

\section{Tipul A de comportament și sursele de stres la locul de muncă}

$\mathrm{Cu}$ toate că majoritatea studiilor care au examinat tipul A de comportament și stresorii la locul de muncă au utilizat măsurători globale ale acestui construct, rezultatele acestora au fost diferite, uneori contradictorii. Burke și Weir (1980) au arătat că Tipul A de comportament se asoci- ază cu valori ridicate ale încărcării muncii și cu un număr crescut de evenimente percepute ca stresante la locul de muncă (Day \& Jreige, 2002). Jamal (1990) a indicat că acest pattern comportamental se asociază cu valori ridicate ale ambiguităţii şi conflictului de rol. Unii autori au relatat faptul că Tipul A de comportament se asociază cu o lipsă a stresorilor legați de muncă, cum ar fi controlul ridicat (Kushmir \& Melamed, 1991; apud. Day \& Jreige, 2002) şi cu utilizarea deprinderilor (Burke \& Weir, 1980; apud. Day \& Jreige, 2002). Aceste diferențe la nivelul rezultatelor pot fi datorate naturii multidimensionale a Tipului A de comportament.

Datorită problemelor metodologice și conceptuale ale utilizării măsurii globale a Tipului A de comportament, Edwards, Baglioni și Cooper (1990) au accentuat importanța utilizării dimensiunilor sale specifice în cercetare. Kivimaki și colaboratorii săi (1996), utilizând două dintre componentele Tipului A de comportament (sârguinţa și nerăbdarea) au evidențiat că angajații cu o sârguință puternică prezintă un control perceput mai mareasupra muncii şi percep un nivel mai scăzut al ambiguității de rol. Scorurile nerăbdării au fost corelate negativ doar cu o lipsă a posibilităților de dezvoltare (realizare).

Utilizând un design longitudinal, Spector şi O'Connell (1994) au examinat capacitatea predictivă a două dintre componentele Tipului A de comportament în estimarea relatărilor viitoare privind stresorii relaţionați cu munca. Rezultatele studiului au indicat faptul că lupta pentru realizarea scopurilor se asociază pozitiv cu încărcarea muncii şi negativ cu ambiguitatea şi conflictul de rol. În schimb, iritabilitatea/ nerăbdarea a corelat cu o frecvență ridicată a conflictelor interpersonale şi a constrângerilor la locul de muncă. Aceste studii sugerează că sârguința tinde să fie relaționată cu caracteristicile pozitive ale locului de muncă, în timp ce iritabilitatea/nerăbdarea pare să fie relaționată cu cele negative.

\section{Tipul A de comportament și reacțiile la stresul ocupațional}

Un studiu longitudinal realizat în SUA printre polițişti și pompieri a indicat că Tipul A de 
comportament a prezis bolile cardiovasculare dezvoltate ulterior (Schaubroeck, Gangster \& Kemerer, 1994). Deși tipul A de comportament, considerat drept construct unidimensional, a prezentat relații modeste cu variabilele fiziologice, cele legate de muncă (satisfacția cu munca, performanța în muncă, burnout, absenteism) şi sănătate (Jamal, 2000), recent s-a sugerat că, datorită naturii sale multidimensionale, folosirea subcomponentelor sale ar putea crește validitatea predictivă a acestui construct (Edwards \& Baglioni, 1991; Jamal, 2007).

Rezultatele unor cercetări indică o asociere pozitivă între nerăbdare și simptomele negative privind starea de sănătate (Spector \& O'Connell, 1994; Spence et al., 1987, Day \& Jreige, 2002), depresia (Bluen, Barling \& Burns, 1990), anxietatea (Volkmer \& Feather, 1991) și infecțiile respiratorii (Barling \& Charbonneau, 1992). Kivimaky și colaboratorii săi (1996) au identificat că atât sârguința, cât și nerăbdarea au fost relaţionate cu simptomele psihologice și fiziologice, direcțiile de asociere fiind însă diferite.

În cadrul acestor linii de cercetare, s-a identificat pe de o parte o asociere pozitivă a Tipului A de comportament global și a celor două subcomponente (competitivitate şi presiunea timpului) cu problemele de sănătate, burnout-ul, intenția de a părăsi organizația, iar pe de altă parte o asociere negativă cu satisfacția muncii și angajamentul organizațional.

\section{Rolul moderator al Tipului A de comportament și al subcomponentelor acestuia în cadrul relației stresori-reacții la stres}

Studiile care au abordat rolul moderator al Tipului A de comportament au utilizat de cele mai multe ori măsurători globale ale acestuia. Jamal (1990; apud. Day \& Jreige, 2002) a arătat că Tipul A de comportament luat ca și construct unidimensional moderează relaţia dintre stresorii la locul de muncă și reacțiile psihosociale la stres. Astfel, persoanele caracterizate de Tipul A de comportament la un nivel ridicat, au relatat mai multe consecințe negative produse de stresorii de la locul de muncă.
Alte studii au arătat că diferite componente ale Tipului A de comportament moderează diferit relațiile existente între stresori și reacțiile la stres (Day \& Jreige, 2002). Componenta iritabilitate/nerăbdare moderează relaţia dintre supraîncărcarea muncii şi satisfacția cu munca. Astfel că, valori crescute ale acestei dimensiuni tind să fie asociate cu o mai mare susceptibilitate la încărcarea muncii în comparație cu valorile scăzute ale iritabilității. Cea mai scăzută satisfacție au raportat-o persoanele care prezentau un grad ridicat de încărcare al muncii și valori crescute ale iritabilității/ nerăbdării. În schimb, sârguința moderează relația dintre controlul asupra activității de muncă și satisfacția cu munca. Mai specific, atunci când controlul asupra muncii este mare, persoanele care manifestă un nivel mai ridicat de ambiție-energie prezintă un nivel mai crescut al satisfacției în muncă în comparație $\mathrm{cu}$ persoanele care manifestau un grad scăzut de ambiție. Rezultatele studiului au evidențiat că valori ridicate ale ambiției sau sârguinței pot reduce reacțiile negative la stres. Alte studii s-au axat pe nerăbdare şi impulsivitate ca elemente componente ale Tipului A de comportament (Pitariu, 2004).

$\mathrm{Cu}$ toate că există un interes crescând pentru studierea stresului ocupaţional în munca de poliție, aceste studii s-au focalizat mai degrabă pe identificarea stresorilor specifici și nu pe rolul Tipului A de comportament în cadrul stresului ocupațional în munca de poliție.

\section{Obiectivele și ipotezele cercetării}

Obiectivul general al studiului este acela de a examina rolul dimensiunilor Tipului A de comportament (nerăbdare și impulsivitatea) în relația dintre factorii generatori de stres şi reacțiile la acești stresori în munca de poliție. Mai specific, în cadrul acestui studiu se urmărește examinarea rolului predictiv al elementelor Tipului A de comportament asupra reacțiilor la stres şi al efectului moderator al acestor elemente în relația stresori-reacții la stres. Ipotezele studiului sunt următoarele:

1a. Nerăbdarea se va asocia negativ cu satisfacția muncii (satisfacția față de locul de muncă și față de organizație). 
1b. Impulsivitatea se va asocia negativ cu satisfacția muncii (satisfacția față de locul de muncă și față de organizație).

2a. Nerăbdarea se va asocia negativ cu starea de sănătate mentală (mulțumirea, activismul şi liniştea sufletească).

2b. Impulsivitatea se va asocia negativ cu starea de sănătate mentală (mulțumirea, activismul și liniştea sufletească).

3a. Nerăbdarea se va asocia negativ cu starea de sănătate fizică(comportamentul temperat şi energia).

3b. Impulsivitatea se va asocia negativ cu starea de sănătate fizică (comportamentul temperat și energia).

4a. Nerăbdarea va modera relația dintre stresorii ocupaționali și reacțiile la stres (angajații care percep un nivel crescut de tensiune generată de stresorii ocupaţionali și au scoruri mari la nerăbdare vor raporta reacții negative la stres mai puternice în comparație cu angajații care percep un nivel crescut de tensiune generată de stresorii ocupaționali și au scoruri mici la nerăbdare).

4b. Impulsivitatea va modera relația dintre stresorii ocupaționali şi reacțiile la stres (angajaţii care percep un nivel crescut de tensiune generată de stresorii ocupaţionali şi au scoruri mari la impulsivitate vor raporta reacții negative la stres mai puternice în comparație cu angajații care percep un nivel crescut de tensiune generată de stresorii ocupaționali și au scoruri mici la impulsivitate).

\section{Metoda}

\section{Participanți}

În cadrul cercetării de față au fost incluși 108 poliţişti din cadrul unei singure organizații. Aceștia au fost selecționați prin intermediul unei proceduri de eşantionare stratificate multistadiale, respectându-se proporția în funcție de sex, vârstă și serviciul în care îşi desfăşoară activitatea. Media de vârstă a participanților este de 34.29 (AS=8.44). Majoritatea participanților la studiu sunt de genul masculin (90\%). Din totalul angajaților polițiști incluşi în studiu, $75.9 \%$ ocupă o funcție de execuție iar restul de $14.1 \%$ au o funcție de conducere. Vechimea în organizație a polițiștilor variază de la 8 luni la 35.2 ani.

\section{Instrumente de investigare}

Pentru a evalua variabilele incluse în modelul de lucru, au fost utilizate scale din Indicatorul de Stres Ocupațional-2 (OSI-2; Cooper, Sloan, \& Williams, 1988)care cuprinde 6 scale şi 18 subscalece măsoară sursele şi efectele presiunilor socioprofesionale, mecanismele de coping şi diferențelele individuale (Pitariu, 2004; Siu, Lu \& Cooper, 1999; Williams \& Cooper, 1998). În studiul de faţă au fost utilizate scale care au măsurat:

1. Opt surse de presiune socioprofesională: supraîncărcarea muncii (6 itemi, $\alpha=.84$ ), relațiile interpersonale ( 8 itemi, $\alpha=.87$ ), recunoaşterea meritelor (3 itemi, $\alpha=.78)^{\star}$, climatul organizațional (4 itemi, $\alpha=.70$ ), responsabilitatea personală (4 itemi, $\alpha=.72$ ), rolul managerial (4 itemi, $\alpha=.60$ ), echilibrul muncă-familie (6 itemi, $\alpha=.78$ ) şi tracasări cotidiene (5 itemi, $\alpha=.66$ ). Sarcina participanților a fost aceea de a evalua măsura în carediverse aspecte ale muncii constituie o sursă de tensiune, utilizând o scală de tip Likert cu 6 trepte ( 1 = categoric nu este sursă de tensiune; 6 = categoric este sursă de tensiune).Un scor ridicat pe toate cele optsubscale indică o puternică tensiune profesională.

2. Diferențele individuale (variabile moderatoare) evaluate prin intermediul a două scale care evaluează componente ale Tipului A de comportament: nerăbdarea ( 3 itemi, $\alpha=.68$ ) și impulsivitatea (3 itemi, $\alpha=.66$ ). Participanții au fost rugați să înregistreze, pe o scală de la 1 la 6 , măsura în care li se potrivesc o serie de afirmații ( 1 = dezacord pronunțat; $6=$ acord pronunțat). Un scor ridicat indică un pattern comportamental de tip A.

3. Efectele presiunilor socioprofesionale sunt reprezentate de:

- satisfacția muncii evaluată prin intermediul a două subscale. Prima subscală care măsoară gradul de satisfacție în relație cu munca cuprinde 6 itemi, în studiul de față coeficientul

* În cazul acestei scale a fost eliminat un item pentru a îmbunătăți coeficientul de fidelitate al scalei, numărul inițial de itemi fiind 4 iar $\alpha=.62$. 
de consistență á al acestei scale fiind de .73. Satisfacția față de organizație este evaluată prin intermediul a 6 itemi $(\alpha=.84)$. Polițiştii aveau sarcina de a estima pe o scală de tip Likert de la 1 la 6 gradul de satisfacție pe care îl simt față de muncă și organizația în care lucrează ( 1 = foarte multă insatisfacție; 6 = foarte multă satisfacție).

- sănătatea mentală. Participanților li s-a cerut să răspundă la o serie de întrebări legate mulțumire (5 itemi, $\alpha=.77$ ), activism (4 itemi, $\alpha=.71$ ) și liniște sufletească (3 itemi, $\alpha=.70$ ), prin încercuirea unei cifre dintr-o scală de tip Likert care să reflecte cel mai bine răspunsul lor la aceste întrebări $(1=$ foarte adevărat, $6=$ foarte neadevărat).

- sănătatea fizică evaluată prin subscalele: comportament temperat ( 3 itemi, $\alpha=.84$ ) şi energie (3 itemi, $\alpha=.72$ ). Pentru estimarea nivelui de sănătate fizică, sarcina participanților era aceea de a nota frecvența cu care au simțit/resimțit simptomele listate în chestionar (de ex. senzația de sufocare sau amețeală). Această evaluare s-a realizat pe o scală de tip Likert cu 6 trepte $(1=$ niciodată, 6 = foarte frecvent).

\section{Procedura}

Chestionarul a fost aplicat colectiv, pe grupe, celor 108 polițiști. În momentul distribuirii chestionarelor, participanților la studiu le-au fost oferite informații privind obiectivele studiului. Totodată li s-a spus că datele obținute pe baza chestionarelor vor fi informative cu privire la elaborarea unor programe care să optimizeze calitatea vieții profesionale de polițist.

\section{Rezultate}

Rezultatele analizei descriptive univariate și bivariate a variabilelor măsurate prin intermediul Indicatorului de Stres Ocupaţional-2 (OSI-2) sunt prezentate în Tabelul 1.

Pentru testarea ipotezelor studiului se va aplica analiza de regresie multiliniară prin metoda ierarhică. Variabilele dependente care vor fi incluse în studiu sunt: satisfacția la locul de muncă, satisfacția cu organizația, mulțumirea, activismul, liniștea sufletească, comportamentul temperat și energia. Pentru fiecare variabilă criteriu se va realiza câte o analiză de regresie. Paşii fiecărei analize de regresie sunt următorii:

Pasul 1 - variabilele controlate (vârstă, gen);

Pasul 2 - stresorii ocupaționali (încărcarea muncii, echilibrul muncă-familie, rolul managerial, responsabilităţi personale, recunoașterea meritelor, climatul organizațional, tracasările cotidiene);

Pasul 3 - componentele Tipului A de comportament (nerăbdarea, impulsivitatea);

Tabelul 1. Analiza descriptivă univariată (media și abaterea standard) şi bivariată (r Bravais-Pearson) a variabilelor incluse în studiu $(\mathrm{N}=108)$

\begin{tabular}{|c|c|c|c|c|c|c|c|c|c|c|c|c|c|c|c|c|c|}
\hline Variabila & 1 & 2 & 3 & 4 & 5 & 6 & 7 & 8 & 9 & 10 & 11 & 12 & 13 & 14 & 15 & 16 & 17 \\
\hline$m$ & 20.76 & 32.44 & 18.59 & 12.81 & 12.64 & 14.51 & 12.67 & 12.25 & .19 & 14.29 & 24.96 & 22.03 & 24.04 & 19.73 & 11.94 & 16.44 & 14.42 \\
\hline SD & 7.09 & 8.4 & 5.72 & 3.66 & 4.01 & 3.85 & 3.97 & 4.23 & 3.65 & 3.01 & 3.82 & 5.07 & 5.04 & 3.84 & 3.36 & 2.52 & 3.01 \\
\hline 1. Încărcarea muncii & 1 & & & & & & & & & & & & & & & & \\
\hline 2. Relații interpersonale & $.70^{\star *}$ & 1 & & & & & & & & & & & & & & & \\
\hline 3. Echilibrul muncă-familie & $.60^{\star *}$ & $.58^{\star \star}$ & 1 & & & & & & & & & & & & & & \\
\hline 4. Rol managerial & $.45^{\star \star}$ & $.46^{\star \star}$ & $.52^{\star \star}$ & 1 & & & & & & & & & & & & & \\
\hline 5. Responsabilități & $.58^{\star *}$ & $.46^{\star *}$ & $.56^{\star \star}$ & $.56^{\star *}$ & 1 & & & & & & & & & & & & \\
\hline 6. Recunoașterea muncii & $.63^{\star \star}$ & $.74^{\star *}$ & $.65^{\star \star}$ & $.57^{\star \star}$ & $.52^{\star *}$ & 1 & & & & & & & & & & & \\
\hline 7. Climat organizational & $.56^{\star *}$ & $.55^{\star \star}$ & $.54^{\star \star}$ & $.38^{\star \star}$ & $.60^{\star *}$ & $.50^{* *}$ & 1 & & & & & & & & & & \\
\hline 8. Tracasări cotidiene & $.59^{\star *}$ & $.58^{\star \star}$ & $.40^{\star *}$ & $.48^{\star *}$ & $.53^{\star \star}$ & $.46^{* *}$ & $.60^{\star *}$ & 1 & & & & & & & & & \\
\hline 9. Nerăbdare & .18 & .11 & .18 & .07 & .07 & $.24^{*}$ & .05 & .15 & 1 & & & & & & & & \\
\hline 10. Impulsivitate & .05 & .01 & .02 & .05 & .05 & .05 & -.01 & .09 & .125 & 1 & & & & & & & \\
\hline 11. Satisfactia cu munca & $-.21^{*}$ & $-.31^{\star \star}$ & -.12 & -.07 & -.16 & -.10 & $-.32^{\star \star}$ & $-.25^{\star \star}$ & -.03 & .04 & 1 & & & & & & \\
\hline 12. Satisfacția cu organizația & $-.28^{\star \star}$ & $-.34^{\star *}$ & -.09 & -.09 & -.11 & -.15 & $-.31^{\star *}$ & $-.31^{\star *}$ & -.03 & .15 & $.70^{\star *}$ & 1 & & & & & \\
\hline 13. Mulțumire & $-.32^{\star \star}$ & $-.20^{\star \star}$ & $-.31^{\star *}$ & $-.34^{\star *}$ & $-.21^{\star}$ & $-.32^{* *}$ & $-.26^{\star \star}$ & $-.36^{\star *}$ & $-.45^{\star \star}$ & .10 & .03 & .03 & 1 & & & & \\
\hline 14. Activism & .03 & .07 & -.12 & .01 & -.02 & .06 & -.04 & .04 & -.16 & -.17 & -.004 & -.04 & $.35^{\star \star}$ & 1 & & & \\
\hline 15. Liniște sufletească & -.13 & $-.20^{\star}$ & -.17 & -.18 & -.12 & $-.31^{\star *}$ & $-.26^{\star \star}$ & -.18 & $-.40^{\star *}$ & .02 & -.12 & -.15 & $.65^{\star \star}$ & .16 & 1 & & \\
\hline 16. Comportament temperat & $-.29^{\star \star}$ & $-.25^{\star \star}$ & $-.29^{\star *}$ & -.13 & -.18 & $-.24^{*}$ & $-.27^{\star \star}$ & $-.26^{\star \star}$ & $-.42^{\star \star}$ & .06 & .18 & $.24^{*}$ & $-.41^{\star \star}$ & $.29^{\star \star}$ & $.21^{*}$ & 1 & \\
\hline 17. Energie & $-.32^{\star *}$ & -.17 & $-.28^{\star *}$ & $-.30^{\star *}$ & -.09 & $-.23^{*}$ & $-.23^{\star}$ & $-.30^{\star *}$ & $-.47^{\star \star}$ & -.13 & .13 & .17 & $.50^{\star \star}$ & $.30^{\star \star}$ & $.30^{* *}$ & $.65^{\star \star}$ & 1 \\
\hline
\end{tabular}

${ }^{\star *}$ Corelația este semnificativă la pragul de $\mathrm{p}<.01$.

* Corelația este semnificativă la pragul de $p<.05$. 
Pasul 4 - interacţiunea dintre sursele de presiune socio-profesionale şi cele două componente ale Tipului A de comportament.

Realizarea analizei de regresie cu primii trei paşi permite identificarea influenței componentelor Tipului A de comportament asupra reacțiilor la stres, în condițiile în care se controlează influența variabilelor demografice și a stresorilor asupra reacțiilor la stres. Introducerea pasului 4 în analiza de regresie permite identificarea efectului moderator al nerăbdării și sârguinței în relația dintre stresori-reacții la stres.
În ceea ce privește predicția satisfacției muncii de către cele două componente ale Tipului A de comportament, datele au evidențiat faptul că nerăbdarea și impulsivitatea nu prezic cele două fațete ale satisfacției cu munca: satisfacția cu locul de muncă și satisfacția cu organizația $(\mathrm{F}(2,93)=.33, \mathrm{p}>.05 ; \mathrm{F}(2,93)=1.32, \mathrm{p}>.05)$. Astfel, primele două ipoteze ale studiului (1a și 1b) nu au primit susținere empirică (Tabelul 2).

Dimensiunile Tipului A de comportament explică însă semnificativ o parte din varianța elementelor stării de sănătate mentală: mulțumi-

Tabelul 2. Rezultatele analizei de regresie având ca variabilă dependentă satisfacția cu locul de muncă şi față de organizație $(\mathrm{N}=108)$

\begin{tabular}{|c|c|c|c|c|c|c|c|c|}
\hline \multirow{3}{*}{ Variabile } & \multicolumn{4}{|c|}{ Satisfacția cu munca } & \multicolumn{4}{|c|}{ Satisfacțiafață de organizație } \\
\hline & Pas 1 & Pas 2 & Pas 3 & Pas 4 & Pas 1 & Pas 2 & Pas 3 & Pas 4 \\
\hline & $\beta$ & $\beta$ & $\beta$ & $\beta$ & $\beta$ & $\beta$ & $\beta$ & $\beta$ \\
\hline \multicolumn{9}{|l|}{ Variabile demografice } \\
\hline Gen & .16 & .15 & .16 & .27 & .06 & .10 & .08 & .17 \\
\hline Vârstă & .17 & .17 & .17 & .18 & $.19^{*}$ & .18 & .18 & $.28^{* *}$ \\
\hline \multicolumn{9}{|l|}{ Stresori ocupaționali } \\
\hline Încărcarea muncii & & .01 & .02 & .08 & & -.10 & -.09 & .03 \\
\hline Relații interpersonale & & $-.43^{\star *}$ & $-.45^{\star \star}$ & $-.33^{\star}$ & & $-.36^{*}$ & $-.36^{\star}$ & $-.34^{*}$ \\
\hline Balanța muncă-familie & & .12 & .13 & .04 & & .17 & .18 & .19 \\
\hline Rol managerial & & .02 & .01 & .05 & & .00 & .00 & .14 \\
\hline Responsabilități personale & & -.05 & -.05 & -.02 & & .14 & .13 & .08 \\
\hline Recunoaștere & & .20 & .23 & .11 & & .10 & .11 & -.15 \\
\hline Climat organizațional & & -.20 & -.21 & -.28 & & -.24 & -.24 & -.28 \\
\hline Tracasări cotidiene & & -.02 & -.01 & -.04 & & -.08 & -.09 & -.03 \\
\hline \multicolumn{9}{|c|}{ Elemente comportament Tip A } \\
\hline Nerăbdare & & & -.07 & .01 & & & -.05 & -.05 \\
\hline Impulsivitate & & & .01 & .03 & & & .14 & .09 \\
\hline \multicolumn{9}{|l|}{ Stresori X Dimensiuni Tip A } \\
\hline Nerăbdare X PW & & & & -.25 & & & & -.01 \\
\hline Nerăbdare X PR & & & & .25 & & & & .22 \\
\hline Nerăbdare $\mathrm{X} \mathrm{PH}$ & & & & .03 & & & & -.07 \\
\hline Nerăbdare X PM & & & & .25 & & & & .14 \\
\hline Nerăbdare X PP & & & & -.27 & & & & -.30 \\
\hline Nerăbdare X PC & & & & -.24 & & & & -.25 \\
\hline Nerăbdare X PO & & & & .25 & & & & .06 \\
\hline Nerăbdare X PD & & & & -.19 & & & & -.09 \\
\hline Impulsivitate X PW & & & & -.16 & & & & -.18 \\
\hline Impulsivitate X PR & & & & .00 & & & & -.11 \\
\hline Impulsivitate $\mathrm{XPH}$ & & & & .15 & & & & -.04 \\
\hline Impulsivitate X PM & & & & .15 & & & & .27 \\
\hline Impulsivitate X PP & & & & -.12 & & & & -.27 \\
\hline Impulsivitate X PC & & & & -.08 & & & & .22 \\
\hline Impulsivitate X PO & & & & .06 & & & & -.02 \\
\hline Impulsivitate X PD & & & & .10 & & & & .23 \\
\hline$F$ & 2.66 & $2.69^{\star \star}$ & $2.26^{*}$ & $1.78^{\star}$ & 2.12 & $3.11^{\star \star}$ & $2.83^{\star \star}$ & $2.16^{\star \star}$ \\
\hline $\mathrm{R}^{2}$ & .04 & .22 & .22 & .39 & .04 & .24 & .26 & .44 \\
\hline F schimbare & 2.66 & $2.62^{*}$ & .33 & 1.33 & 2.12 & $3.26^{\star *}$ & 1.32 & 1.48 \\
\hline$\Delta \mathrm{R}^{2}$ & .04 & .17 & .00 & .16 & .04 & .20 & .02 & .17 \\
\hline
\end{tabular}

** Coeficientul F, F schimbare, â este semnificativ la $p<.01$

* Coeficientul F, F schimbare, â este semnificativ la $p<.05$

Notă: $\mathrm{PW}=$ Încărcarea muncii; $\mathrm{PR}=$ Relații profesionale; $\mathrm{PH}=$ Balanța muncă-familie; $\mathrm{PM}=$ Rolul managerial; $\mathrm{PP}=\mathrm{Responsabilități} \mathrm{personale;}$ $\mathrm{PC}=$ Recunoașterea meritelor; $\mathrm{PO}=$ Climatul organizațional; $\mathrm{PD}=$ Tracasări cotidiene 
Tabelul 3. Rezultatele analizei de regresie având ca variabilă dependentă mulțumirea, activismul și liniștea sufletească ca elemente ale sănătăţii mentale $(\mathrm{N}=108)$

\begin{tabular}{|c|c|c|c|c|c|c|c|c|c|c|c|c|}
\hline \multirow{3}{*}{ Variabile } & \multicolumn{4}{|c|}{ Mulțumire } & \multicolumn{4}{|c|}{ Activism } & \multicolumn{4}{|c|}{ Liniște sufletească } \\
\hline & Pas 1 & Pas 2 & Pas 3 & Pas 4 & Pas 1 & Pas 2 & Pas 3 & Pas 4 & Pas 1 & Pas 2 & Pas 3 & Pas 4 \\
\hline & $\beta$ & $\beta$ & $\beta$ & $\beta$ & $\beta$ & $\beta$ & $\beta$ & $\beta$ & $\beta$ & $\beta$ & $\beta$ & $\beta$ \\
\hline \multicolumn{13}{|l|}{ Variabile demografice } \\
\hline Gen & $-.29^{\star \star}$ & $-.24^{*}$ & -.18 & -.20 & .04 & -.04 & .00 & -.08 & -.14 & -.17 & -.14 & -.18 \\
\hline Vârstă & $-.31^{\star *}$ & $-.35^{\star \star}$ & $-.34^{\star \star}$ & $-.46^{\star \star}$ & -.06 & -.09 & -.08 & -.11 & $-.28^{\star \star}$ & $-.23^{\star}$ & $-.23^{*}$ & $-.31^{* *}$ \\
\hline \multicolumn{13}{|l|}{ Stresori ocupaționali } \\
\hline Încărcarea muncii & & -.20 & -.18 & $-.33^{\star}$ & & .00 & .01 & -.07 & & .15 & .18 & .03 \\
\hline Relații interpersonale & & $.38^{\star}$ & $.28^{*}$ & .26 & & .09 & .03 & .04 & & .10 & .01 & .08 \\
\hline Balanța muncă-familie & & -.21 & -.17 & -.18 & & -.34 & -.31 & -.24 & & -.01 & .03 & .03 \\
\hline Rol managerial & & -.22 & $-.23^{\star}$ & -.26 & & -.01 & -.04 & -.09 & & -.02 & -.07 & -.02 \\
\hline Responsabilități personale & & .20 & .19 & .31 & & .04 & .03 & -.03 & & .16 & .13 & .17 \\
\hline Recunoaștere & & .01 & .09 & .15 & & .25 & .31 & $.44^{*}$ & & -.28 & -.17 & -.13 \\
\hline Climat organizațional & & -.13 & -.14 & -.11 & & -.10 & -.12 & -.21 & & -.30 & $-.34^{\star}$ & $-.29^{*}$ \\
\hline Tracasări cotidiene & & $-.30^{\star}$ & $-.24^{*}$ & -.24 & & .06 & .11 & .17 & & -.06 & .00 & -.04 \\
\hline \multicolumn{13}{|c|}{ Elemente comportament Tip A } \\
\hline Nerăbdare & & & $-.33^{\star *}$ & $-.33^{\star *}$ & & & -.16 & -.08 & & & $-.36^{\star \star}$ & $-.34^{\star *}$ \\
\hline Impulsivitate & & & .01 & -.07 & & & -.15 & -.33 & & & .08 & .07 \\
\hline \multicolumn{13}{|c|}{ Stresori X Dimensiuni Tip A } \\
\hline Nerăbdare X PW & & & & -.28 & & & & $-.38^{\star}$ & & & & -.11 \\
\hline Nerăbdare X PR & & & & .04 & & & & -.15 & & & & -.08 \\
\hline Nerăbdare X PH & & & & -.11 & & & & -.09 & & & & .08 \\
\hline Nerăbdare X PM & & & & .08 & & & & -.09 & & & & -.05 \\
\hline Nerăbdare X PP & & & & -.13 & & & & $.43^{*}$ & & & & -.08 \\
\hline Nerăbdare X PC & & & & -.26 & & & & .28 & & & & .23 \\
\hline Nerăbdare X PO & & & & .19 & & & & -.16 & & & & .01 \\
\hline Nerăbdare X PD & & & & -.14 & & & & -.16 & & & & .13 \\
\hline Impulsivitate X PW & & & & .38 & & & & $.44^{*}$ & & & & .21 \\
\hline Impulsivitate X PR & & & & -.09 & & & & .02 & & & & -.08 \\
\hline Impulsivitate $\mathrm{X} \mathrm{PH}$ & & & & -.15 & & & & -.24 & & & & .02 \\
\hline Impulsivitate X PM & & & & -.19 & & & & .13 & & & & -.04 \\
\hline Impulsivitate X PP & & & & .08 & & & & -.10 & & & & -.10 \\
\hline Impulsivitate X PC & & & & .01 & & & & -.10 & & & & -.10 \\
\hline Impulsivitate X PO & & & & -.04 & & & & .22 & & & & -.21 \\
\hline Impulsivitate X PD & & & & -.22 & & & & -.23 & & & & -.02 \\
\hline $\mathrm{F}$ & $9.71^{\star \star}$ & $5.94^{\star *}$ & $7.16^{\star \star}$ & $3.78^{\star *}$ & .33 & .86 & 1.18 & $2.16^{\star \star}$ & $4.95^{\star \star}$ & $2.44^{*}$ & $3.73^{\star *}$ & $1.93^{*}$ \\
\hline $\mathrm{R}^{2}$ & .16 & .40 & .50 & .60 & .00 & .08 & .13 & .44 & .08 & .20 & .32 & .41 \\
\hline F schimbare & $9.71^{\star *}$ & $4.32^{\star *}$ & $8.31^{\star *}$ & 1.12 & .33 & .99 & 2.57 & $2.64^{\star \star}$ & $4.95^{\star \star}$ & 1.74 & $8.28^{\star \star}$ & .72 \\
\hline$\Delta R^{2}$ & .16 & .23 & .09 & .10 & .00 & .07 & .05 & .30 & .08 & .11 & .12 & .08 \\
\hline
\end{tabular}

** Coeficientul F, F schimbare, â este semnificativ la $\mathrm{p}<.01$

* Coeficientul F, F schimbare, â este semnificativ la $p<.05$

Notă:PW= Încărcarea muncii; $\mathrm{PR}=$ Relații profesionale; $\mathrm{PH}=$ Balanța muncă-familie; $\mathrm{PM}=$ Rolul managerial; $\mathrm{PP}=\mathrm{Responsabilități} \mathrm{personale;}$ $\mathrm{PC}=$ Recunoașterea meritelor; $\mathrm{PO}=$ Climatul organizațional; $\mathrm{PD}=$ Tracasări cotidiene

rea $\left(\Delta \mathrm{R}^{2}=9 \%\right)$ și liniștea sufletească $\left(\Delta \mathrm{R}^{2}=12 \%\right)$ (Tabelul 3).

La nivel analitic, datele evidenţiază faptul că dintre cele două componente studiate ale Tipului A de comportament, doar nerăbdarea este asociată negativ mulțumirea $(\beta=-.33, p<.05)$ şi liniștea sufletească $(\beta=-.36, p<.05)$. Valoarea coeficienților $\beta$ asociați nerăbdării arată că poliţiștii care sunt intoleranţi şi simt un grad ridi- cat de frustrare atunci când sunt împiedicați în realizarea obiectivelor de muncă vor relata o stare de mulțumire şi de linişte sufletească mai redusă în comparație cu persoanele cu nerăbdare scăzută. Nici una dintre componentele Tipului A de comportament nu contribuie la estimarea semnificativă a activismului $(\mathrm{F}(2,93)=2.57$, p>.05) în condițiile în care se controlează influența variabilelor demografice şi a stresorilor. 
Datele obținute indică faptul că ipoteza $2 \mathrm{a}$ a fost susţinută parțial empiric, iar ipoteza $2 \mathrm{~b}$ nu a primit susţinere empirică deoarece impulsivitatea nu a prezis nici una dintre componentele stării de sănătate mentală.

În schimb, rezultatele analizei de regresie în care variabilele dependente sunt elementele stării de sănătate fizică (comportamentul temperat și energia) indică faptul că nerăbdarea și impulsivitatea estimează semnificativ atât evoluția comportamentului temperat, $\mathrm{F}(2,93)=8.90, \mathrm{p}<.01$, cât şi evoluția nivelului de energie $(\mathrm{F}(2,93)=12.05$, $\mathrm{p}<.01$ ) (Tabelul 4). Analizând ponderea fiecărei faţete a Tipului A de comportament în estimarea variabilelor dependente se constată că nerăbdarea prezice negativ atât comportamentul tem-

Tabelul 4. Rezultatele analizei de regresie având ca variabilă dependentă comportamentul temperat şi energia ca elemente ale sănătății fizice $(\mathrm{N}=108)$

\begin{tabular}{|c|c|c|c|c|c|c|c|c|}
\hline \multirow{3}{*}{ Variabile } & \multicolumn{4}{|c|}{ Comportament temperat } & \multicolumn{4}{|c|}{ Energie } \\
\hline & Pas 1 & Pas 2 & Pas 3 & Pas 4 & Pas 1 & Pas 2 & Pas 3 & Pas 4 \\
\hline & $\beta$ & $\beta$ & $\beta$ & $\beta$ & $\beta$ & $\beta$ & $\beta$ & $\beta$ \\
\hline \multicolumn{9}{|l|}{ Variabile demografice } \\
\hline Gen & -.16 & -.16 & -.12 & -.18 & $-.19^{\star}$ & -.15 & -.08 & -.12 \\
\hline Vârstă & .00 & .00 & .00 & .02 & .12 & .07 & .08 & .07 \\
\hline \multicolumn{9}{|l|}{ Stresori ocupaționali } \\
\hline Încărcarea muncii & & -.02 & -.00 & -.02 & & -.23 & -.21 & -.29 \\
\hline Relații interpersonale & & .04 & -.05 & -.06 & & $.32^{*}$ & .20 & .24 \\
\hline Balanța muncă-familie & & -.18 & -.12 & -.07 & & -.21 & -.14 & -.10 \\
\hline Rol managerial & & .09 & .03 & .09 & & -.23 & $-.30^{\star *}$ & $-.30^{*}$ \\
\hline Responsabilități personale & & .01 & -.01 & -.14 & & $.38^{\star *}$ & $.35^{\star *}$ & .27 \\
\hline Recunoaștere & & -.01 & .11 & .10 & & -.01 & .12 & .16 \\
\hline Climat organizațional & & -.14 & -.17 & -.23 & & -.22 & $-.26^{*}$ & -.29 \\
\hline Tracasări cotidiene & & -.15 & -.09 & -.01 & & -.16 & -.07 & -.04 \\
\hline \multicolumn{9}{|c|}{ Elemente comportament Tip A } \\
\hline Nerăbdare & & & $-.38^{* *}$ & $-.33^{\star *}$ & & & $-.40^{\star \star}$ & $-.33^{\star \star}$ \\
\hline Impulsivitate & & & .11 & .00 & & & -.05 & -.13 \\
\hline \multicolumn{9}{|l|}{ Stresori X Dimensiuni Tip A } \\
\hline Nerăbdare X PW & & & & -.14 & & & & -.23 \\
\hline Nerăbdare X PR & & & & -.02 & & & & .04 \\
\hline Nerăbdare X PH & & & & -.05 & & & & -.02 \\
\hline Nerăbdare XPM & & & & -.12 & & & & -.07 \\
\hline Nerăbdare XPP & & & & .21 & & & & .23 \\
\hline Nerăbdare XPC & & & & .01 & & & & .00 \\
\hline Nerăbdare XPO & & & & -.04 & & & & .09 \\
\hline Nerăbdare XPD & & & & -.18 & & & & -.15 \\
\hline Impulsivitate XPW & & & & .25 & & & & .29 \\
\hline Impulsivitate XPR & & & & .00 & & & & -.10 \\
\hline Impulsivitate XPH & & & & .05 & & & & .09 \\
\hline Impulsivitate XPM & & & & .20 & & & & .07 \\
\hline Impulsivitate XPP & & & & -.20 & & & & -.22 \\
\hline Impulsivitate XPC & & & & -.21 & & & & -.18 \\
\hline Impulsivitate XPO & & & & -.12 & & & & .00 \\
\hline Impulsivitate XPD & & & & .02 & & & & -.06 \\
\hline $\mathrm{F}$ & 1.44 & 1.55 & $2.99^{\star \star}$ & $1.97^{\star}$ & $3.26^{*}$ & $3.37^{\star *}$ & $5.47^{\star \star}$ & $2.87^{\star \star}$ \\
\hline $\mathrm{R}^{2}$ & .02 & .14 & .27 & .41 & .06 & .26 & .41 & .51 \\
\hline F schimbare & 1.44 & 1.56 & $8.90^{\star *}$ & 1.14 & $3.26^{\star}$ & $3.25^{\star \star}$ & $12.05^{\star \star}$ & .95 \\
\hline$\ddot{A} R^{2}$ & .02 & .11 & .13 & .13 & .06 & .20 & .15 & .09 \\
\hline
\end{tabular}

** Coeficientul F, F schimbare, â este semnificativ la p<.01

* Coeficientul F, F schimbare, â este semnificativ la p<.05

Notă: $\mathrm{PW}=$ Încărcarea muncii; $\mathrm{PR}=$ Relații profesionale; $\mathrm{PH}=$ Balanța muncă-familie; $\mathrm{PM}=$ Rolul managerial; $\mathrm{PP}=\mathrm{Responsabilități} \mathrm{personale;}$ $\mathrm{PC}=$ Recunoașterea meritelor; $\mathrm{PO}=$ Climatul organizațional; $\mathrm{PD}=$ Tracasări cotidiene 
perat $(\beta=-.38, p<.01)$, cât și energia polițiștilor $(\beta=-.40, p<.01)$. Valoarea negativă a coeficienților $\beta$ asociați nerăbdării semnalează că polițiștii care resimt un grad ridicat de frustrare atunci când sunt împiedicați în realizarea obiectivelor de muncă vor fi mai predispuşi la dezvoltarea unor simptome de natură fizică (oboseală, lipsă de energie, senzații de amețeală etc.) în comparație cu polițiștii ce prezintă un nivel scăzut al nerăbdării. Datele obținute în studiul de față susțin empiric doar ipoteza $3 a$ deoarece, în cazul ipotezei $3 b$, impulsivitatea nu a fost asociată nici unui element al stării de sănătate fizice a polițiștilor.

În ceea ce privește efectele de moderare, datele obținute evidențiază faptul că nerăbdarea și sârguința nu moderează relațiile dintre stresori și reacțiile la stresreprezentate de satisfacția cu locul de muncă $(\mathrm{F}(16,77)=1.33$, $\mathrm{p}>.05)$, satisfacția organizațională $(\mathrm{F}(16,77)=1.48$, $\mathrm{p}>.05)$, mulțumirea față de confortul psihologic $(F(16,77)=1.12, p>.05)$, liniștea sufletească $(\mathrm{F}(16,77)=.72, \mathrm{p}>.05)$, comportamentul temperat $(F(16,77)=1.14, p>.05)$ şi nivelul de energie $(\mathrm{F}(16,77)=.95, \mathrm{p}>.05)$.

Efecte de moderare ale dimensiunilor Tipului A de comportament au fost evidențiate în cazul activismului ca reacție la stres $(F(16,77)=2.64, p<.01)$.Nerăbdarea moderează relația dintre încărcarea muncii și activism, în sensul că angajații care percep o încărcare cu sarcini și au un nivel redus de răbdare vor raporta un nivel de activism mai mare în comparație cu angajații care percep o încărcare cu sarcini și au un nivel crescut al nerăbdării $(\beta=-.38, p<.05)$. Datele obținute evidențiază faptul că polițiștii care percep un nivel crescut al tensiuni create de responsabilitățile personale de la locul de muncă și au un nivel crescut de nerăbdare vor relata un nivel mai scăzut de activism în comparație cu polițiștii care percep o tensiune crescută datorată responsabilităților personale de la locul de muncă și care au un nivel redus de nerăbdare $(\beta=.43, \mathrm{p}<.05)$. Similar, angajații care percep o tensiune datorată încărcării muncii și au un nivel de impulsivitate crescut raportează un nivel mai scăzut al activismului în comparație cu angajații care percep un nivel crescut de tensiune datorată încărcării cu sarcini de muncă dar au un nivel scăzut de impulsivitate $(\beta=.44, \mathrm{p}<.05)$. Astfel, ipotezele privind rolul moderator al dimensiunilor Tipului A de comportament primit parțial susținere empirică.

\section{Discuții și concluzii}

Obiectivul general al studiului de față a fost acela de a investiga rolul dimensiunilor Tipului A de comportament (nerăbdarea și sârguința) în relația dintre factorii generatori de stres și reacțiile la stres în munca de poliție reprezentate de satisfacția față de locul de muncă şi organizație, mulțumirea față de confortul psihologic, activismul, liniștea mentală, comportamentul temperat și nivelul de energie.

Analiza intercorelațiilor dintre sursele presiune socio-profesională arată că fiecare stresor evaluat se asociază pozitiv cu ceilalți stresori. Acesta este un aspect care ar trebui luat în considerare şi care ar putea face obiectul unor discuții cu polițiştii, în sensul de a fi învăţaţi să distingă între diferite surse de stres prin interpretarea corectă a acestora. Astfel, dacă un polițist este în relații tensionate cu colegii, nu înseamnă că va fi mai puțin recompensat la locul de muncă, că i se va oferi mai mult de lucru, etc.

În analizele de regresie efectuate, nerăbdarea a constituit un predictor negativ al elementelor stării de sănătate fizică (comportament temperat, energie) și mentală (mulțumire, liniște sufletească). Polițiștii care sunt intoleranți și simt un grad ridicat de frustrare atunci când sunt împiedicați în realizarea obiectivelor de muncă vor fi mai predispuşi la dezvoltarea unor simptome de natură fizică (oboseală, lipsă de energie, senzații de amețeală etc.) şi vor relata o stare de mulțumire și de liniște sufletească mai redusă în comparație cu angajații ce prezintă un nivel scăzut al nerăbdării. Direcția predicției dintre nerăbdare și reacţiile la stres subliniază încă o dată natura „toxică“ a acestui element al Tipului A de comportament, în relație cu starea de sănătate percepută. În studiul de față impulsivitatea nu a fost relaționată cu nici una dintre reacțiile stres. Cele două componente ale Tipului A de comportament nu au prezis nivelul de satisfacție al polițiștilor, rezultat care este în contradicție cu cele existente în literatura de specialitate. Studiile evidențiază însă faptul că 
sârguinţa este asociată cu un nivel de satisfacție mai mare cu munca (Day \& Jreige, 2002). În ceea ce privește rolul predictiv al nerăbdării în relație cu starea de sănătate mentală și fizică, rezultatele obținute în studiul prezent sunt în concordanță cu cele existente în literatura de specialitate (de exemplu, Spector \& O'Connel, 1994).

În ceea ce privește rolul moderator al Tipului A de comportament în relația stresori-reacții la stres, studiul de față nu a evidențiat un efect de moderare al dimensiunilor Tipului A de comportament în cazul variabilelor dependente reprezentate de satisfacția cu munca, satisfacția față de organizație, mulțumire față de starea de bine, linişte sufletească, comportament temperat, energie. În cazul activismului, ca element al sănătății mentale, au fost identificate efecte de moderare ale nerăbdării asupra încărcării în muncă și responsabilităților personale, respectiv ale impulsivității asupra încărcării în muncă.

Una dintre explicațiile posibile pentru lipsa de detecție a efectului de moderare, precum şi a unora dintre relațiile de predicție este reprezentată de fidelitatea scăzută a unora dintre scalele instrumentului utilizat. Din categoria stresorilor, scalele care evaluează rolul managerial și tracasările cotidiene prezintă o fidelitate sub pragul acceptat de 0.70 . Pe lângă fidelitatea scăzută a acestora, există și o consistență internă scăzută a variabilelor considerate ca fiind moderatoare în cadrul modelului conceptual al OSI-2: nerăbdarea $(\alpha=.68)$, impulsivitatea $(\alpha=.66)$. Unii autori atenționează asupra faptului că utilizarea unor instrumente de măsurare cu fidelitate redusă sau instrumente diferite care măsoară același concept poate reduce șansele evidențierii unor relații de predicție şi de moderare (Day \& Jreige, 2002). Studiile efectuate în direcția testării proprietăților instrumentului OSI-2 indică o fidelitate scăzută, în special a scalelor care măsoară variabilele individuale, cu precădere Tipul A de comportament. În unele situații, fidelitatea obținută prin metoda înjumătățirii pentru scalele care evaluează variabilele moderatoare din OSI-2 a fost de 0.20 sau 0.10 (Steiler \& Pati, 2009). Studiile ulterioare au reușit să îmbunătățească fidelitatea acestor scale, însă nu la pragul dorit (Brown \& Cooper, 1996; Steiler \& Cooper, 2004). În plus, modelul conceptual al OSI-2 nu oferă indicații privind relațiile dintre variabile (Steiler \&
Pati, 2009), fiind considerat un model liniar al stresului ocupațional. Pe baza rezultatelor obținute prin acest studiu, putem spune că, pentru a reduce problemele de sănătate fizice și emoționale ale polițiștilor ca reacții la stresul ocupațional nu este suficientă o diminuare a solicitărilor şi tensiunilor ocupaţionale ale muncii. Este necesar să luăm în considerare o gamă cât mai largă de variabile: atât factorii individuali (de exemplu, vârsta, dimensiunile comportamentului de tip A, etc.), cât și cei de mediu (de exemplu, încărcarea muncii) relaționați în literatura de specialitate cu simptomatologia psiho-somatică.

Se impune însă și o anumită precauție în interpretarea rezultatelor, întrucât datele au fost colectate prin intermediul scalelor de tip autodeclarativ. Folosirea măsurilor de tip self-report în studiul de faţă crește posibilitatea ca rezultatele noastre să fie contaminate de distorsiunea mono-metodei. Rezultatele pot fi distorsionate în cazul metodelor auto-declarative, mai ales în cazul scalelor reactivității la stres, de dorința subiecților de a obține o evaluare pozitivă la aceste scale şi de a evita posibilele penalități la locul de muncă. Studiile viitoare ar putea include măsurători obiective ale surselor de muncă generatoare de stres, variabilelor moderatoare și reacțiilor la stres la care să se adauge măsurători fiziologice ale stării de sănătate. În plus, pentru o mai bună convergență a datelor privind stresul ocupaţional în munca de poliție, studiile ulterioare ar putea combina metodologia cantitativă cu cea calitativă (Liu, Spector \& Shi, 2008).

În plus, Indicatorul de Stres Ocupațional-2 este un chestionar mai larg, multidimensional, care a fost creat pentru a măsura stresul ocupațional al angajaților care ocupă o poziție înaltă în cadrul ierarhiei organizaționale. O limită a acestuia este că evaluează doar stresori generici şi eșuează în a încorpora acei stresori care sunt unici diverselor ocupații cu risc crescut de stres. În plus, sunt chestionate proprietăţile psihometrice ale instrumentelor generice de evaluare a stresului ocupațional din cadrul diferitelor ocupații profesionale (McCreary \& Thompson, 2006). Pornind de la aceste neajunsuri ale instrumentelor multidimensionale, largi de evaluare a stresului ocupațional, McCreary şi Thompson (2006) au sugerat crearea unor măsurători specifice ocupațiilor stresante, cum ar fi munca de poliție. 
Un alt aspect care trebuie luat în considerare pe viitor este introducerea în modelele de regresie și altor variabile demografice care au fost citate în literatura de specialitate ca fiind relaționate în mod semnificativ cu dimensiunile tipului A de comportament: structura de poliție (Ordine Publică, Investigații Criminale, Criminalistică, etc.), respectiv regiunea geografică din care provin participanții. Studii privind variabilele demografice în cadrulstresului ocupațional la ofițerii de poliție din UK postulează existența unor diferențe în tipul A de comportament între polițiști, în funcție de structura de poliție din care provin (Kop \& Euwema, 2001 apud. Burke \& Mikkelsen, 2006; Kirkcaldy, Brown \& Cooper, 1998; Kirkcaldy \& Cooper, 1992). Aceste studii au evidențiat faptul că în rândul ofițerilor de poliție care lucrează în branșa „,detectivilor“ de criminali (Structura de Investigații Criminale) a predominat un pattern comportamental de tip A (agresiv, dominator și dogmatic) spre deosebire de ofițerii din cadrul altor structuri. Acesta s-a asociat pozitiv cu un nivel ridicat al satisfacţiei cu munca și negativ cu probleme de sănătate, îndeosebi boli cardiovasculare. În continuarea acestui demers aplicativ, s-ar putea studia dacă selecția profesională în branşa ofițerilor investigativi a presupus atragerea unor personalități de tip A sau dacă acest tipar de comportament a fost dezvoltat și încurajat de mediul muncii.

Referitor la examinarea multidimensionalităţii Tipului A de comportament, Day şi Jreige (2002) sugerează că studiile viitoare ar trebui să investigheze şi alte dimensiuni ale Tipului A de comportament, cum ar fi cele identificate de Edwards și colaboratorii (1990): competitivitatea, ostilitatea, ambiția, lupta pentru realizare și nerăbdarea/iritabilitatea. $\mathrm{O}$ altă componentă a Tipului A de comportament care a căpătat în ultimul timp o atenție deosebită din partea cercetătorilor este criza de timp, care se referă la percepția timpului ca o sursă valoroasă, punând accent pe utilizarea planificată şi atentă a timpului (Burnam, Pennenbaker \& Class, 1975; apud. Pitariu \& Landy, 1993). Deși în trecut conceptul de criză de timp era abordat ca un concept unidimensional (Jenkins, Zysanski \& Roseman, 1971), Conte, Landy și Mathieu (1995) au arătat că acest construct este de fapt unul multidimen- sional și că elementele sale s-ar putea comporta diferit în cadrul stresului ocupațional.

Completarea datelor obținute în studiul prezent cu studii privind rolul mai multor componente ale Tipului A de comportament în cadrul stresului ocupaţional va permite schițarea unor strategii de management al stresului ocupaţional în scop preventiv și de intervenție primară și secundară în munca de poliție bazate pe:

- identificarea polițiștilor care prezintă caracteristicile indezirabile ale pattern-ului comportamental de Tip A (nerăbdare, ostilitate) prin introducerea în evaluările psihologice periodice a scalelor Tipului A de comportament;

- proiectarea unui program de management al stresului ocupațional prin reducerea focalizării obsesive pe timp, a furiei, a nerăbdării și a ostilității care survin la polițiștii de Tip A când întâmpină anumite obstacole în activitatea profesională. Studiile au evidențiat faptul că o conceptualizare a Tipului A de comportament în termeni de comportament multidimensional permite realizarea unor intervenții de succes pentru a reduce elementele ,toxice“ ale acestuia asupra calității vieții profesionale a polițiștilor (Karlberg, Krakau, \& Undén, 1997).

\section{Bibliografie}

Abdollahi, M.K. (2002). Understanding police stress research. Journal of Forensic Psychology Practice, 2, 1-24.

Antoniu, A.S. (2009). Occupation-specific precursors of stress among Greek police officers: the roles of rank and gender. International Journal of Police Science \& Management, 11, 3, 334-344.

Barling, J. \& Charbonneau, D. (1992). Disentangling the relationship between achievement striving and impatience-irritability dimensions of type A behaviour, performance and health. Journal of Organizational Behaviour, 13, 369-377.

Bluen, S.D., Barling, J., \& Burns, W. (1990). Predicting sales performance, job satisfaction and depression by using the achievement strivings and impatience - irritability dimensions of Type A behavior. Journal of Applied Psychology, 75, 212-216.

Blumenthal, J. A.\& Herman, S. (1985). Age differences in self-perception of Type A traits. Journal of Consulting and Clinical Psychology, 53, 264-266.

Booth-Kewley, S. \& Friedman, H.S. (1987). Psychological predictors of heart disease: A quantitative review. Psychological Bulletin, 101, 343-362. 
Brown, J. \& Cooper, C. (1996).Occupational stress among senior police officers.British Journal of Psychology, 87, 31-41.

Burke, R. J. \& Mikkelsen, A. (2006). Examining the career plateau amongpolice officers.International Journal of Police Strategies and Management, 29, 4, 691-703.

Capotescu, R. (2006). Stresul ocupațional- Teorii, modele, aplicații. Iași: Editura Lumen.

Conte, J.M., Landy, F.J. \& Mathieu, J.E. (1995). Time urgency: Conceptual and construct development. Journal of Applied Psychology, 80, 178-185.

Contrada, R.J. (1989). Type A behavior, personality hardiness, and cardiovascular responses to stress. Journal of Personality and Social Psychology,57, 895-903.

Cooper, C.L., Sloan, S.J. \& Williams, S. (1988). The Occupational Stress Indicator. Windsor: NFER Nelson.

Day, L.A., \& Jreige, S. (2002). Examining Type A behaviour pattern to explain the relationship between job stressors and psychosocial outcomes. Journal of Occupational Health Psychology, 7, $109-120$

Dick, P. (2000). The social construction of the meaning of acute stressors: a qualitative study of the personal accounts of police officers using a stress counseling service. Work and Stress, 226-244.

Dollard, M.F. \& Winefield, A.H. (1998). A Test of the demand-control/support model of work stress in correctional officers.Journal of Occupational Health Psychology. 3, 3, 243-264.

Edwards, R.J. \& Baglioni, Jr. A.J. (1991). Relationship between Type A behavior pattern and mental and physical symptoms: A comparison of global and component measures. Journal of Applied Psychology, 76, 276-290.

Edwards, R.J., Baglioni, Jr. A.J. \& Cooper, C.L. (1990). Examining the relationships among self-report measures of the Type A behaviour pattern: The effects of dimensionality, measurement error, and differences in underlying constructs. Journal of Applied Psychology, 75, 440-454.

Frees, M. (1999). Social support as a moderator of the relationship between work stressors and psychological dysfunctioning: A longitudinal study with objective measures. Journal of Occupational Health Psychology, 4, 3, 179-192.

Friedman, H.S. \& Booth-Kewley, S. (1987). Personality, Type A behavior, and coronary heart disease: The role of emotional expression. Journal of Personality and Social Psychology, 53, 783-792.

Kirkcaldy, B.D. \& Cooper, C.L. (1992). Cross-cultural differences in occupational stress among British and German Managers. Work and Stress, 6, 2, 177-190.

Kirkcaldy, B.D., Cooper, C.L. \& Brown, J., (1998). The demographics of occupational stress among police superintendents. Journal of Managerial Psychology, 13, 2, 90-101.

Jamal, M. (1990). Relationship of job stress and TypeA behavior to employees' job satisfaction, organizational commitment, psychosomatic health problems, and turnover motivation. Human Relations, 43, 8, 727-738.

Jamal, M. \& Baba, V. V. (2003). Type A behavior, components, and outcomes: A study of Canadian employees. International Journal of Stress Management, 10, 39-50.

Jamal, M. (2007). Type A behavior in a multinational organization: A study of two countries. Stress and Health, 23, 101-109.

Jenkins, C.D., Zyzanski, S.J. \& Rosenman, R.H. (1971). Progress toward validation of computerscored test for the type A coronary-prone behavior pattern. Psychosomatic Medicine, 33, 193-202

Jones, B., Flynn, D.M. \& Kelloway, E.K. (1995).Perceptions of support from the organization in relation towork stress, satisfaction, and commitment. In Sauter, S.L. and Murphy, L.R. (Eds.).Organizational riskfactors for job stress. Washington, DC: American Psychological Association.

Karlberg, L., Krakau, I. \& Undén, A.-I. (1997). Type A behavior intervention in primary health care reduces hostility and time pressure: A study in Sweden. Social Sciences \& Medicine, 46, 3, 397402.

Kivimäki, M., Raija, K. \& Julkunen, J. (1996). Components of type A behavior pattern and occupational stressor-strain relationship: Testing different models in a sample of industrial managers. Behavioral Medicine, 22, 2, 67-76.

Lazarus, R.S., DeLongis, A., Folkman, S., \& Gruen, R. (1985). Stress and adaptation outcomes: The problem of confounded measures. American Psychologist, 40, 770-779.

Liu, C., Spector, P.E. \& Shi, L. (2008). Use of both qualitative and quantitative approaches to study stress in different gender and occupational groups. Journal of Occupational Health Psychology, 13, 4, 357-370.

Malach-Pines, A. \& Keinan, G. (2007). Stress and burnout in Israeli police officers during a Palestinian uprising (Intifada). International journal of management Stress, 14, 2, 160-174.

Matthews, K.A. (1988). Coronary heart disease and Type A behaviors: Update on and alternative to the Booth-Kewley and Friedman (1987) quantitative review. Psychological Bulletin, 104, 373-380.

McCreary, D.R. \& Thompson, M.M. (2006). Development of two reliable and valid measures of stressors in policing: The operational and organizational police stress questionnaires. International Journal of Stress Management, 13, 4, 494-518.

Mikkelsen, A. \& Burke, R. J. (2004). Work-family concerns of Norwegian police officers: Antecedents 
and consequences. International Journal of Stress Management, 11, 4, 429-444.

Pitariu, H.D. \& Landy, F.J. (1993). Some personality correlates of time urgency. Revue Roumaine de Psychology, 37, 1, 15-25.

Pitariu, H.D. (2004). Stresul profesional la manageri: Corelative ale personalității în contextual situației de tranziție social-economică din România. In Opre, A. (Ed.): Noi tendințe în psihologia personalității. Diagnoză, cercetare, aplicații (2). ClujNapoca: ASCR.

Schaubroeck, J., Ganster, D.C., \& Kemmerer, B.E. (1994). Job complexity, „Type A“ behavior, and cardiovascular disorder: A prospective study. Academy of Management Journal, 37, 2, 426-439.

Siu, O., Lu L. \& Cooper C.L. (1999). Managerial stress in Hong Kong and Taiwan: a comparative study. Journal of Managerial Psychology, 14, 1, 6-25.

Sonnentag, S. \& Jelden, S. (2009). Job stressors and the pursuit of sport activities: A day-level perspective. Journal of Occupational Health Psychology, 14, 2, 165-181.

Spector, P.E. \& O’Connell, B. J. (1994). The contribution of personality traits, negative affectivity, locus ofcontrol and Type A to the subsequent reports of job stressors and job strains.Journal of Occupational andOrganizational Psychology, 67, 1-11.

Spence, J.T., Helmreich, R.L. \& Pred, S.R. (1987). Impatience versus achievement striving in the
Type A pattern: Differential effects on student's health and academic achievement. Journal of Applied Psychology,72, 522-528.

Steiler, D. \& Paty, B. (2009).French version of the Occupational Stress Indicator (OSI).Revue Européenne de Psychologie Appliequée, 59, 113122.

Steiler, D. \& Cooper, C.L. (2004). French version of the Occupational Stress Indicator (OSI): Preliminary assessment of reliability and validity. Stress and Health, 20, 231-237.

Stichcomb, J.B. (2004). Searching for stress in all the wrong places: Combating chronic organizational stressors in policing. Police Practice and Research, 5, 3, 259-277.

Strube, M.J., Berry, J.M., Goza, B.K. \& Fennimore, D. (1985). Type A behavior, age, and psychological well-being. Journal of Personality and Social Psychology,49, 203-218.

Volkmer, R.\& Feather, N. (1991).Relations between type A scores, internal locus of control and test anxiety. Personality and Individual Differences, 12, 2, 205-209.

Williams, S. \& Cooper, C.L. (1998). Measuring occupational stress: Development of the Pressure Management Indicator. Journal of Occupational Health Psychology, 3, 306-321. 